DEPARTMENT OF THE INTERIOR UNITED STATES GEOLOGICAL SURVEY

A CONTRIBUTION OF THE, NATIONAL CENTER FOR EARTHQUAKE RESEARCH

PREPARED IN COOPERATION WITH THE

CALIFORNIA DIVISION OF MINES AND GEOLOGY

\title{
MAP SHOWING RECENTLY ACTIVE BREAKS ALONG THE SAN ANDREAS AND RELATED FAULTS BETWEEN THE NORTHERN GABILAN RANGE AND CHOLAME VALLEY, CALIFORNIA \\ By \\ Robert D. Brown, Jr.
}

MISCELLANEOUS GEOLOGIC INVESTIGATIONS
MAP I-575

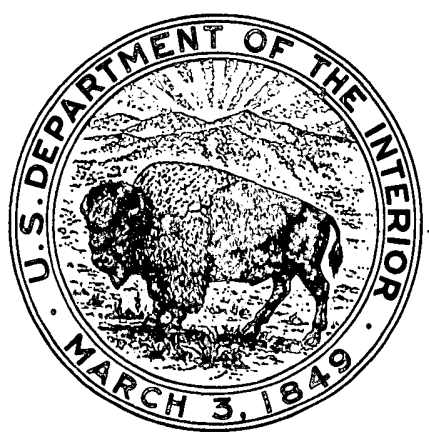

PUBLISHED BY THE U. S. GEOLOGICAL SURVEY 